\title{
Identifying Different Populations of Sulphate-reducing Bacteria within Marine Sediment Systems, Using Fatty Acid Biomarkers
}

\author{
By JAMES TAYLOR† AND R. JOHN PARKES* \\ Scottish Marine Biological Association, Dunstaffnage Marine Research Laboratory, PO Box 3 , \\ Oban, Argyll PA34 4AD, UK
}

(Received 28 August 1984; revised 1 November 1984)

\begin{abstract}
The distribution of lipid fatty acids was studied in marine sediment slurries in which sulphate reduction had been stimulated by the addition of acetate, propionate, lactate or hydrogen. Acetate was directly oxidized to carbon dioxide at the expense of sulphate, propionate was incompletely oxidized to acetate at the expense of sulphate, and lactate was largely fermented (approximately $75 \%$ ) to propionate and acetate, with the propionate subsequently utilized for sulphate reduction. Changes in the lipid fatty acids within these slurries were interpreted by comparison with the lipid fatty acid profiles of pure cultures of Desulfovibrio desulfuricans, Desulfobacter sp. and Desulfobulbus sp. Desulfobacter sp. seems to be the main acetate-utilizing sulphate-reducing bacterium, as in both the slurry and the original sediment the lipid fatty acids in the $\mathrm{C}_{12}-\mathrm{C}_{18}$ range (where bacterial contributions would be expected) were dominated by even chain fatty acids similar to the lipid fatty acid distribution of Desulfobacter sp. Desulfobulbus sp. appears to be responsible for propionate oxidation and also for hydrogen consumption as its biomarker fatty acid $\mathrm{n}-\mathrm{C}_{17: 1}$ was increased significantly by the addition of either propionate or hydrogen. Surprisingly, the biomarker for Desulfovibrio desulfuricans (br$\mathrm{C}_{17: 1}$ ) was not stimulated in any of the sediment slurries. The results demonstrate that there are at least two functional groups of sulphate-reducing bacteria in marine systems, and that lipid fatty acid analysis is a useful technique for investigating bacterial distributions within a complex sedimentary environment.
\end{abstract}

\section{INTRODUCTION}

Bacterial sulphate reduction has been shown to be an important process in the degradation of organic matter within marine sediments (Jørgensen, 1982) and in coastal sediments it is responsible for approximately $50 \%$ of the mineralization of organic matter. The main substrates for sulphate reduction within marine sediments seem to be acetate $(60 \%)$, propionate, butyrate and hydrogen (5-10\% each) (Sørensen et al., 1981; Winfrey \& Ward, 1983). Several different types of sulphate-reducing bacteria that are able to utilize such substrates have recently been isolated (Widdel, 1980; Widdel \& Pfennig, 1981, 1982; Pfennig et al., 1981; Widdel et al., 1983), but it remains unclear if the types isolated are indeed responsible for the in situ degradation of these substrates and what their biomass distributions are within the marine environment.

Several techniques are available to enumerate and identify bacterial types present in marine sediments, but all suffer from various limitations (Parkes \& Taylor, 1983a; King \& White, 1977). Culture techniques using selective media were used to enumerate different types of sulphate-reducing bacteria by Laanbroek \& Pfennig (1981). These authors found that colony counts on either acetate or propionate-supplemented medium were consistently lower than counts on a lactate-supplemented medium, which tends to conflict with more recent data indicating that acetate is the main substrate for sulphate-reducing bacteria within marine sediments. However, such results must be interpreted within the limitations of the technique used (see for example Van Es \& Meyer-Reil, 1982) and the discrepancy may reflect the rather

† Present address: British Council, 10 Spring Gardens, London SW1A 2BN, UK. 
non-specific substrate conditions that using lactate provides. Laanbroek \& Pfennig (1981) also clearly demonstrated that the majority of lactate added to sediment slurries was rapidly fermented to produce propionate and acetate; hence colony counts represent more than just lactate-utilizing sulphate-reducing bacterial types and thus may not give a realistic description of the population distribution within the original sediment.

Biochemical methods that quantitatively recover and measure cellular components which reflect biomass and community structure avoid the problems of laboratory isolation of organisms (White, 1983) and therefore may provide more realistic information on the in situ distribution of bacteria. Bacteria contain characteristic lipid fatty acids in the $\mathrm{C}_{12}-\mathrm{C}_{19}$ region (Kates, 1964; Shaw, 1974) which distinguish them from eukaryotic organisms and in certain cases from each other (Lechevalier, 1977, 1982). Such properties enable fatty acids to be used to study complex sedimentary communities in situ, thus avoiding the limitations of isolation techniques (Federle et al., 1983; Gillan et al., 1983; Parkes \& Taylor, 1983a). Recently, Taylor \& Parkes (1983) have shown that the lipid fatty acids of the sulphate-reducing bacteria Desulfobacter, Desulfobulbus and Desulfovibrio desulfuricans contain a number of characteristic acids which have the potential to act as biomarkers for these bacterial types in complex sedimentary environments.

The aim of the current work was to assess the potential of using these biomarker fatty acids as biomass indicators of the different sulphate-reducing bacterial types in complex sedimentary environments and hence to probe the in situ structure of such mixed sulphate-reducing communities. Different types of sulphate-reducing bacteria were selectively stimulated, in marine sediment slurries, by addition of different growth substrates. Oxidation of added substrate was monitored by volatile fatty acid analysis and determination of sulphate and sulphide concentrations. Total biomass stimulation was measured by phospholipid analysis. The structural changes introduced in the sulphate-reducing bacterial populations within the slurries was assessed using lipid fatty acid distributions and viable counts on selective media.

\section{METHODS}

Sampling. Sediment cores approximately $60 \mathrm{~cm}$ in length were obtained using a gravity corer from station E70 in the deep basin of Loch Eil and from station E9 in Loch Etive, enclosed sea lochs on the Scottish west coast (see Pearson, 1981 and Malcolm, 1981, respectively, for further description of these sites). Cores were brought back to the laboratory on ice, and stored at $5^{\circ} \mathrm{C}$ until they were used, which was normally the next day.

Sediment slurries. A section of anoxic Loch Eil sediment $(3-11 \mathrm{~cm}$ depth) from within the active sulphatereducing zone (R. J. Parkes, unpublished data) was removed and placed in a container that was slowly flushed with oxygen free nitrogen. This was then placed into an anaerobic cabinet (Forma Scientific, Oh., USA). The sediment was sieved through a $1000 \mu \mathrm{m}$ sieve with an equivalent volume ( 1 litre) of deoxygenated $50 \%(\mathrm{v} / \mathrm{v})$ sea water. The resultant slurry was thoroughly mixed and distributed in $150 \mathrm{ml}$ amounts into screw cap conical flasks which were then sealed with a septum.

The flasks were removed from the anaerobic cabinet, with subsequent additions or removals being made via the septum. To triplicate flasks were added sodium acetate, sodium propionate and sodium lactate $(1 \mathrm{ml}$ of a $3 \mathrm{M}$ solution made up in deoxygenated $50 \%, \mathrm{v} / \mathrm{v}$, seawater) to provide a final concentration of $20 \mathrm{mM}$. Three flasks with no additions served as controls. All the flasks were flushed for $5 \mathrm{~min}$ with oxygen free nitrogen, leaving the flasks with a slight positive pressure. All the flasks were checked for gas leaks. A sample of slurry from each treatment was taken to provide time zero sulphide and sulphate measurements (see below). The flasks were incubated on an orbital shaker ( 100 r.p.m.) at $20^{\circ} \mathrm{C}$ in the dark.

In a separate experiment with Loch Eil sediment the effect of hydrogen on sulphate reduction was studied. Anaerobic slurries were produced as previously described but duplicate flasks were flushed with $\mathrm{H}_{2} / \mathrm{CO}_{2}(80 / 20$, $\mathrm{v} / \mathrm{v}$ ) instead of nitrogen. Two flasks with no additions and flushed with nitrogen served as controls. Additions of propionate were also made to slurries of Loch Etive sediment in an identical manner to that described for Loch Eil sediments.

Analysis of sediment slurries before extraction. Samples were removed from the flasks with a syringe and then filtered through a pre-combusted glass fibre filter paper (GFF, Whatman) to remove particulate matter. Sulphide was analysed by a colorimetric method (Cline, 1969), and sulphate by titration (Howarth, 1978). Volatile fatty acids were measured on an ion chromatograph (Dionex, Sunnyvale, USA) with prior separation of salts by vacuum distillation (Parkes \& Taylor, 1983 ). For lactate and high concentrations of volatile fatty acids $(>1 \mathrm{~mm})$ the sample was diluted $1: 250$ with double distilled water before analysis; this resulted in good separation of the fatty acids from the anion front without vacuum distillation. A Beckman model $3560 \mathrm{pH}$ meter was used to 
measure pH. Gas analysis was done in a Pye Unicam model 104 gas chromatograph with a katharometer detector. Gases $\left(\mathrm{H}_{2}, \mathrm{CH}_{4}, \mathrm{CO}_{2}\right)$ were separated with nitrogen as the carrier gas $\left(35 \mathrm{ml} \mathrm{min}^{-1}\right)$ on a glass column packed with Porapak Q (Supelco, Penn., USA). The column and detector temperatures were $50{ }^{\circ} \mathrm{C}$ and $100^{\circ} \mathrm{C}$, respectively. Before sampling, the headspace of the flasks was adjusted to atmospheric pressure with a nitrogen filled manometer.

Extraction of sediment slurries. Nonadecanoic acid methyl ester $(150 \mu \mathrm{g})$ as internal standard was added to each slurry before extraction. The slurries were extracted ultrasonically using methanol and dichloromethane (Douglas et al., 1981). The solvent was removed under vacuum and the crude lipid extract saponified by reflux for $2 \mathrm{~h}$ in $1 \mathrm{M}$ $\mathrm{KOH}$ in methanol $(100 \mathrm{ml})$. The procedure for obtaining the lipid fatty acid from the saponification mixture was outlined by Taylor \& Parkes (1983). The acids were methylated with $\mathrm{BF}_{3} / \mathrm{MeOH}$ (Metcalfe \& Schmitz, 1961) and the monocarboxylic acid methyl esters purified by TLC (Taylor \& Parkes, 1983).

Analysis of lipid fatty acids. Fatty acids were analysed as their methyl esters by capillary GLC (Taylor \& Parkes, 1983). The assignment of structure was based on GLC retention times and where possible coinjection with authentic standards on both OV-1 and Carbowax $20 \mathrm{M}$ columns, on argentation TLC, and on MS analysis (Parkes \& Taylor, 1983a). The double bond position of the monounsaturated fatty acids has not been specified since the original double bond assignments of $n-C_{17: 1}$ and $n-C_{15: 1}$ as $\omega 10$ and $\omega 8$ for Desulfobulbus by Taylor \& Parkes (1983) now appear questionable. Mass spectral analysis of their pyrrolidine esters suggests that these monounsaturated acids exhibit double bond positional isomers at $\Delta 9$ and $\Delta 11$ respectively, which are unusual with respect to the current theories of aerobic and anaerobic biosynthesis of cellular fatty acids; further work is currently in progress on their structure and biosynthesis. However, lack of double bond positional assignments does not detract in any way from the conclusions of this paper. Quantification was achieved by reference of peak areas measured by a Hewlett-Packard integrator to that of the added $n-C_{19}$ fatty acid internal standard.

Lipid fatty acid nomenclature. The fatty acids are designated as the number of carbon atoms in the chain and the degree of unsaturation is given as a number separated by a colon from the chain length. The prefix 'br' indicates iso and anteiso branching.

Lipid phosphate analysis. Samples of $5 \mathrm{ml}$ in triplicate of the organic extract were taken for phospholipid analysis by the procedure described by White et al. (1979). Using this procedure recovery of bacteria added to sediments was approximately $98 \%$.

Viable counts. Viable counts of sulphate-reducing bacteria were made using the agar shake technique (Pfennig $e t$ al., 1981) and selective substrates. An increased amount of iron was added to the agar shake medium (66 $\mu \mathrm{g}$ $\mathrm{FeSO}_{4} \cdot 7 \mathrm{H}_{2} \mathrm{O}$ in $9 \mathrm{ml}$ complete medium) to enable active sulphate-reducing colonies to be recognized by the development of blackening around the colony. Despite the presence of sulphide in the culture medium the small amount of extra iron did not precipitate on addition and the medium remained clear. The agar shake tubes were inoculated $(0.1 \mathrm{ml})$ with sediment samples from serial dilutions in anaerobic mineral salts. The dilution series was prepared in an anaerobic cabinet. Agar shakes were incubated at $25^{\circ} \mathrm{C}$ and counted after $30 \mathrm{~d}$.

\section{RESULTS}

\section{Stimulation of sediment sulphate-reducing bacterial biomass}

The incubation of the sediment slurries at $20^{\circ} \mathrm{C}$ was terminated when the supply of added substrate neared exhaustion and sulphate reduction had occurred, as evidenced by a substantial increase in sulphide levels. The major results of these slurry incubation experiments are presented in Table 1, where both the initial and final levels of added substrate, sulphate and sulphide are presented, together with headspace gas analysis (Loch Eil slurries only) and the concentrations of volatile fatty acids present at the end of the incubation. Headspace gas analyses showed complete removal of hydrogen from the $\mathrm{H}_{2} / \mathrm{CO}_{2}$ flask by the end of the incubation. No methane or hydrogen was detected in any of the flasks at the termination of the experiment. At this stage (13 d and 14.8 d, respectively, for Loch Eil and Loch Etive sediments) the slurries were frozen at $-40^{\circ} \mathrm{C}$ until their lipid fatty acids were analysed.

To obtain more detailed information on the anaerobic mineralization pathways of acetate, propionate and L-lactate, a replicate series of Loch Eil slurries was monitored regularly over the $13 \mathrm{~d}$ incubation period; the results for the propionate and lactate incubations are shown in Fig. $1(a$ and $b)$. The measured amounts of all three substrates increased slightly over the first few days, an observation probably linked to equilibrium processes within the slurries. Acetate decreased slowly between days 3 and 8 , after which time a more rapid mineralization occurred with a concomitant increase in sulphide. Propionate (Fig. $1 a$ ) remained relatively constant over the first $8 \mathrm{~d}$ of incubation and then was rapidly oxidized to acetate with concomitant production 


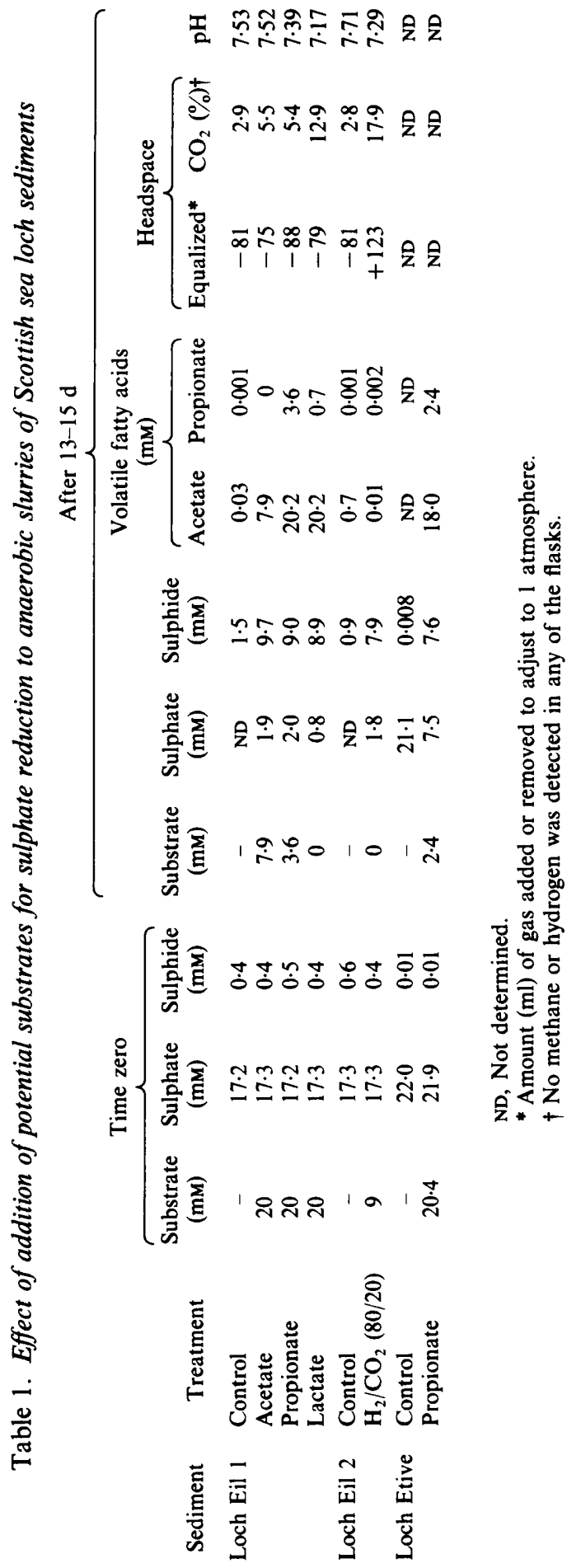




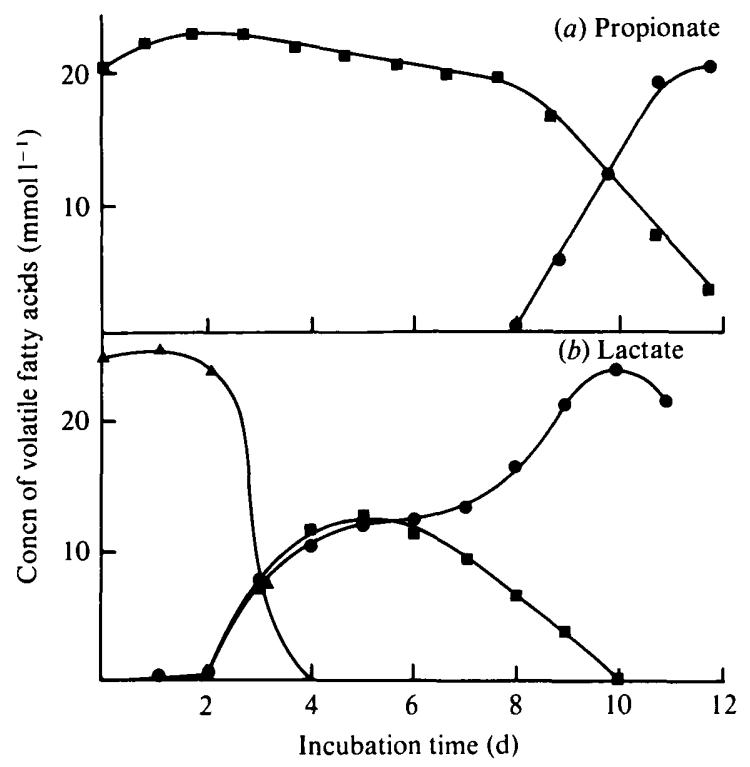

Fig. 1. Anaerobic degradation of volatile fatty acids in marine sediment slurries (Loch Eil) supplemented with $20 \mathrm{mM}$-propionate $(a)$ or $20 \mathrm{~mm}$-lactate $(b)$. , Acetate; $\boldsymbol{\square}$, propionate; $\boldsymbol{\Delta}$, L-lactate.

of sulphide. L-Lactate was completely removed after $4 \mathrm{~d}$ (Fig. $1 b$ ), with production of approximately equal amounts of acetate and propionate between days 2 and 5 . The propionate produced during this period was subsequently oxidized to acetate, with concomitant sulphate reduction, and was completely removed within $10 \mathrm{~d}$.

\section{Lipid fatty acid compositions of sediment slurries}

The lipid fatty acids of the substrate-stimulated slurries from Lochs Eil and Etive were analysed with particular attention being paid to the relative abundance of those fatty acids which had previously been identified as possible biomarkers for various types of sulphatereducing bacteria (Taylor \& Parkes, 1983). Clear differences in the relative fatty acid distributions of the various substrate-stimulated slurries were observed over the $C_{12}-C_{19}$ range, where any bacterial contribution would be expected (Kates, 1964; Shaw, 1974). The major features in the distributions of the slurry fatty acids are given in Table 2 for Loch Eil slurries stimulated by acetate, propionate and lactate and in Table 3 for Loch Eil slurry stimulated by hydrogen and Loch Etive slurry with propionate, as $\mu \mathrm{g}$ per $\mathrm{g}$ dry wt of slurry.

The data in Table 2 were analysed by single classification analysis of variance (Sokal $\&$ Rohlf, 1969) followed by a range simultaneous test procedure to identify which treatments were significantly different. The data in Table 3 were analysed using Student's $t$ test. Acetate stimulation of the sediment slurry gave no significant changes in the lipid fatty acid distribution over the $\mathrm{C}_{12}-\mathrm{C}_{18}$ range compared with the control slurries. In contrast, both propionate and Llactate stimulation resulted in significant increases $(P=0.01)$ in $n-C_{17: 1}$ and $n-C_{15: 1}$ fatty acids. As an example of these increases, Fig. 2 shows the gas-liquid chromatograms of Loch Eil sediment slurry stimulated with propionate and the control slurry. However, when the L-lactate stimulated slurry was analysed after $3 \mathrm{~d}$ no increase in $n-C_{17: 1}$ or $n-C_{15: 1}$ fatty acids was observed, indeed these acids appeared relatively less abundant than in the control.

Stimulation with $\mathrm{H}_{2} / \mathrm{CO}_{2}$ also resulted in a significant increase $(P=0.01)$ in $n-\mathrm{C}_{17: 1}$ fatty acid (Table 3) but no such increase in $n-C_{15: 1}$. In a similar manner to sediment slurries from Loch Eil, addition of propionate to those from Loch Etive resulted in significant increases $(P=0.02$, Table 3) in n-C $\mathrm{C}_{17: 1}$ and $\mathrm{n}-\mathrm{C}_{15: 1}$ fatty acids. In all the stimulated slurries neither the abundance of the even chain $\mathrm{C}_{12}-\mathrm{C}_{18}$ fatty acids nor the br- $\mathrm{C}_{17: 1}$ fatty acids altered significantly relative to the control. 


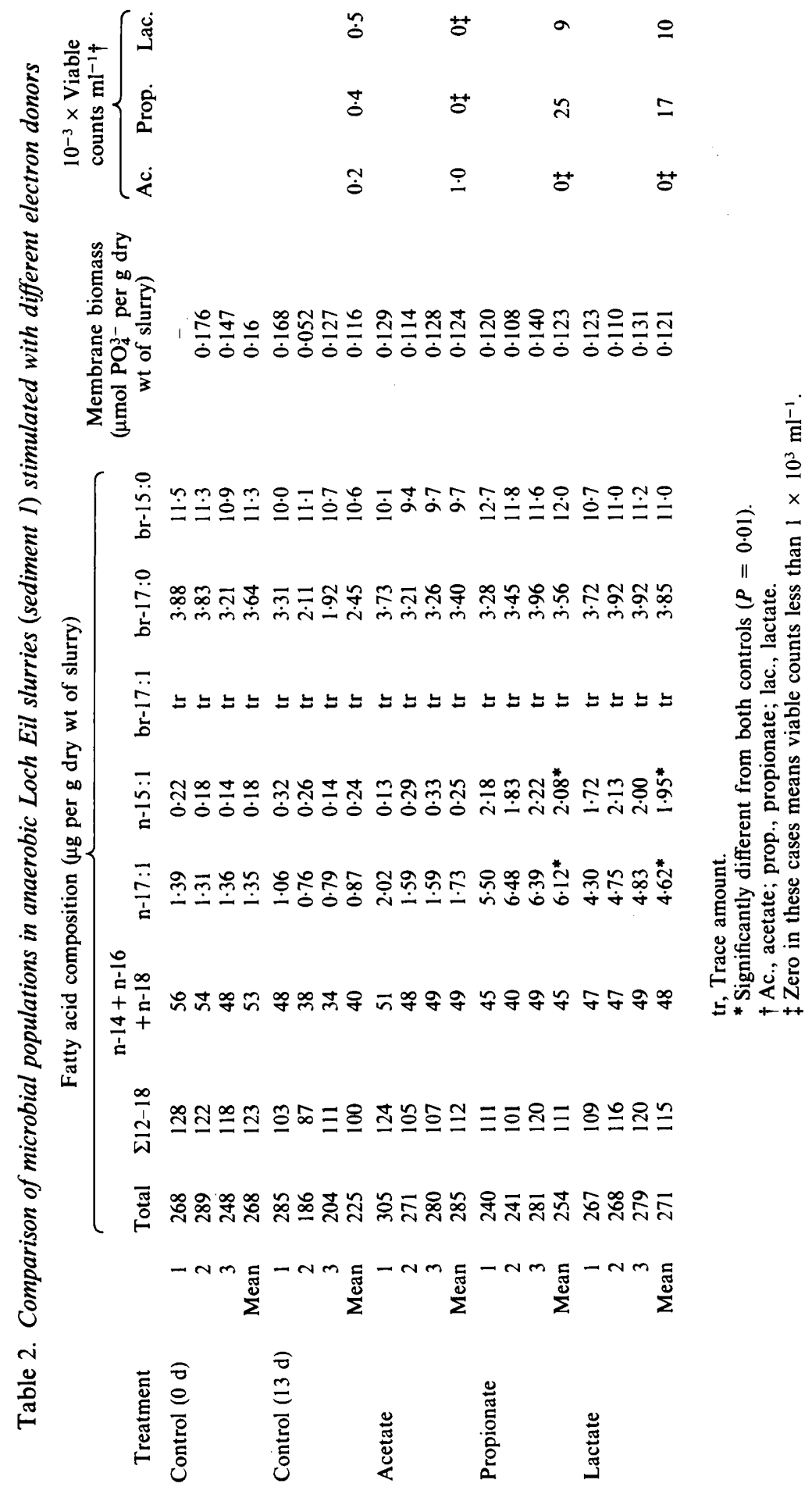




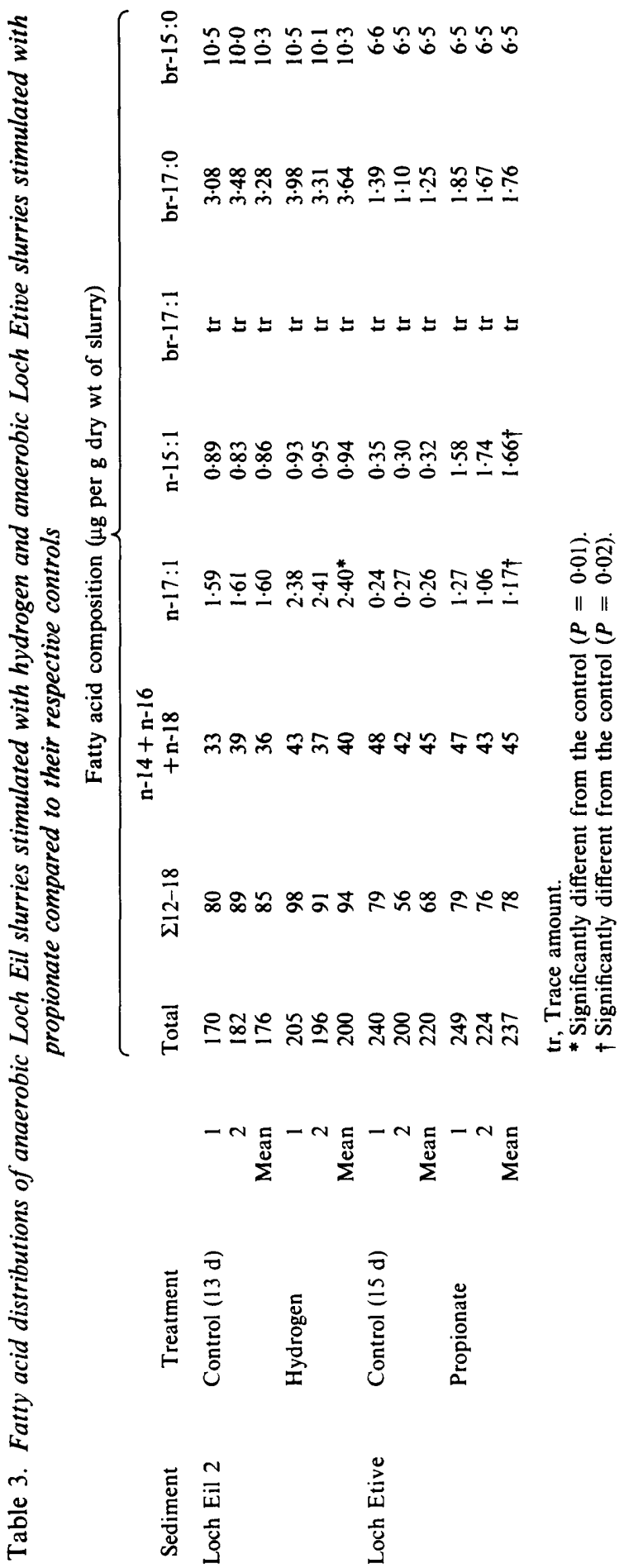




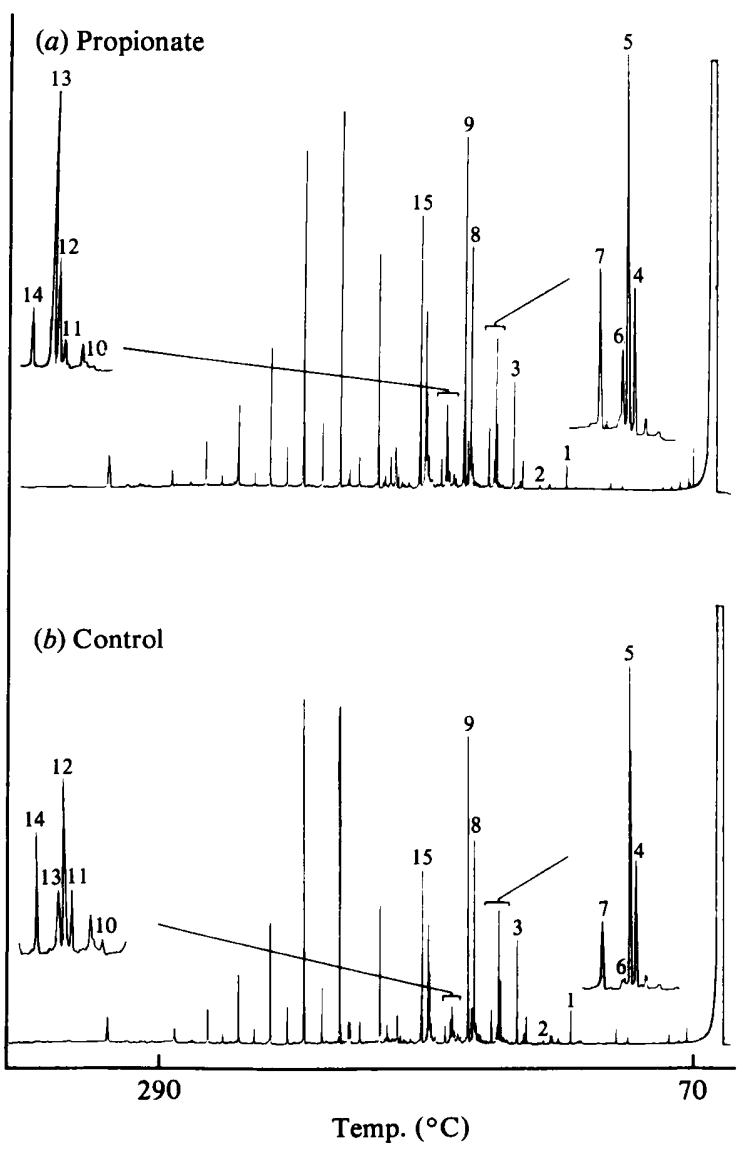

Fig. 2. Gas-liquid chromatograms of fatty acid methyl esters from Loch Eil sediment slurry (a) stimulated with propionate and $(b)$ control. Peak numbers of fatty acids refer to: $1,12: 0 ; 2,13: 0 ; 3$, $14: 0 ; 4$, iso- $15: 0 ; 5$, anteiso- $15: 0 ; 6,15: 1 ; 7,15: 0 ; 8,16: 1 ; 9,16: 0 ; 10$, anteiso-17:1;11, iso-17:0;12, anteiso- $17: 0 ; 13,17: 1 ; 14,17: 0 ; 15,18: 0$.

\section{Viable counts}

Colony counts of sulphate-reducing bacteria showed that their numbers had been increased by the addition of acetate, propionate and lactate to the slurries (Table 2) which is consistent with the observed stimulation in sulphide concentrations within the slurries. Acetate addition only caused an increase in acetate-utilizing sulphate-reducing bacteria, which microscopically were identical to Desulfobacter. Propionate and lactate addition, however, resulted in increased counts in both lactate and propionate agar shakes, but the highest counts in both cases were on propionate medium. In all the lactate agar shakes there was a large number of non-black colonies, presumably due to fermentative bacteria, and these were not counted. In contrast, in both acetate and propionate agar shakes there were few non-black colonies; these colonies were probably due to bacteria using fermentable compounds present in the medium as impurities.

\section{Phospholipids}

The phospholipid content and hence total biomass of all the slurries tended to decrease during the $13 \mathrm{~d}$ incubation period, but in the flasks with substrate added the decrease was less than in the control (Table 2). However, none of the changes were statistically significant. 


\section{DISCUSSION}

Acetate has been demonstrated to be the major substrate for sulphate-reducing bacteria in anoxic marine sediments (Sørensen et al., 1981; Winfrey \& Ward, 1983) and acetate-oxidizing sulphate-reducing bacteria belonging to the genus Desulfobacter (Widdel \& Pfennig, 1981) have been isolated from such sediments. Therefore, it is not surprising that the addition of acetate to a marine sediment slurry resulted in acetate mineralization with concomitant sulphate reduction (Table 1). Similar observations were made by Laanbroek \& Pfennig (1981) and they isolated Desulfobacter-type organisms from the sediment used for the incubation experiments. However, this is not direct evidence to link Desulfobacter sp. with the anaerobic oxidation of acetate via sulphate reduction in a marine environment, since isolation of bacteria by culture enrichments can produce a distorted picture of the dominant organism in situ (see later discussion).

The use of biochemical markers as a means of identifying the distribution of specific organisms in the natural environment overcomes the problems associated with laboratory isolation, and Taylor \& Parkes (1983) suggested, on the basis of lipid fatty acid data, that Desulfobacter-type bacteria may indeed be the dominant sulphate-reducing bacteria within marine sediments, both the sediment and Desulfobacter being dominated by saturated and monounsaturated even chain acids.

However, considerable care has to be exercised in interpreting the presence of biomarkers in the environment as proof of the presence.of a specific organism. The occurrence of biomarkers in laboratory grown organisms may only reflect laboratory growth conditions and not that of the organisms when growing under in situ conditions. Also, although a biomarker appears to be characteristic of a specific organism, there may be other, as yet to be isolated, organisms present in the environment which also contain the biomarker. These problems of interpretation can be minimized if under laboratory conditions the presence of the biomarker can be shown to be independent of growth conditions and if the environment in which the biomarker is being analysed is well characterized and/or controlled. Taylor \& Parkes (1983) analysed the dominant fatty acids of the sulphate-reducing bacteria Desulfobacter sp., Desulfobulbus sp. and Desulfovibrio desulfuricans grown on their main substrates and found certain fatty acids were dominant irrespective of the substrate being utilized. In the current slurry experiments conditions were so controlled as to allow stimulation of basically only sulphate-reducing bacteria and this was indeed the case (Table 1). The only exception was with lactate where fermentative bacteria were stimulated initially (Fig. 1) followed by sulphate-reducing bacteria. It therefore seems reasonable to relate the changes observed in the slurry fatty acid distributions to the biomarker fatty acids for sulphate-reducing bacteria identified by Taylor \& Parkes (1983). There is, however, still the possibility that bacteria yet to be isolated also have these biomarkers, but such bacteria would have to be sulphate-reducing bacteria using identical substrates to those of the laboratory isolates, and hence probably very similar, if not identical, to the existing laboratory isolates.

The results presented here show that stimulation of sulphate reduction by the addition of acetate caused no statistically significant change in the distribution of slurry fatty acids [over the $\mathrm{C}_{12}-\mathrm{C}_{18}$ range, where all bacterial contributions would be expected (Kates, 1964; Lechevalier, 1977)] compared to the control slurries. The fatty acid profile of Desulfobacter $\mathrm{sp}$. is dominated by even chain fatty acids (Taylor $\&$ Parkes, 1983) but these are very common bacterial fatty acids, as indicated by their high concentration in both the slurry time zero control (Table 2) and the original sediment (Parkes \& Taylor, 1983a). Thus it is not surprising with the relatively small biomass stimulation observed in the acetate slurries (Table 2, membrane biomass) that the small increase in even chain fatty acids $\left(\mathrm{C}_{14}+\mathrm{C}_{16}+\mathrm{C}_{18}\right)$ within the same slurries (Table 2) was not statistically significant. There was also no stimulation in any of the other biomarkers for sulphate-reducing bacteria. However, stimulation in the slurry of the acetate-utilizing, sulphatereducing bacterial biomass was confirmed by viable counts (Table 2) and the morphology of the bacteria was consistent with Desulfobacter-type organisms. Together these observations tend to indicate that acetate-utilizing Desulfobacter-type organisms were responsible for acetate oxidation within the acetate-supplemented sediment slurries and were also the dominant sulphate-reducing bacteria in the original sediment, as stimulation by addition of acetate 
resulted in an increase in their viable counts and a small increase in biomass, but not a change in the dominant bacterial fatty acids.

An alternative explanation could be that the biomass of the acetate-utilizing sulphatereducing bacteria has been insufficiently stimulated to cause significant changes in the bacterial fatty acid distribution of the slurry. This explanation, however, seems unlikely as significant changes in bacterial fatty acids were observed with the addition of identical amounts of lactate and propionate to the sediment slurries.

Stimulation of sulphate reduction by the addition of propionate to the slurry resulted in significant increases in the absolute levels of $n-C_{17: 1}$ and $n-C_{15: 1}$ fatty acids (Fig. 2, Table 2), with the concentrations of $n-C_{17: 1} n-C_{15: 1}$ being much higher than in the the control. Both these fatty acids were present when Desulfobulbus sp. was grown on propionate (Taylor $\&$ Parkes, 1983), with $n-C_{17: 1}$ being the dominant fatty acid. Oxidation of the propionate also resulted in a substantial increase in the numbers of propionate-utilizing sulphate-reducing bacteria as evidenced by viable counts (Table 2). The morphology of the stimulated propionate-utilizing sulphate reducers was consistent with their being Desulfobulbus-type organisms. This is strong evidence that Desulfobulbus-type bacteria were responsible for the oxidation of propionate at the expense of sulphate in the slurry and that bacterial fatty acids, especially n- $\mathrm{C}_{17: 1}$, may be useful biomarkers for this organism in marine systems. The incomplete oxidation of propionate to acetate in the sediment slurry (Fig. $1 a$ ) is identical to the observations of Laanbroek \& Pfennig (1981) and consistent with the metabolism of Desulfobulbus (Widdel \& Pfennig, 1981).

The addition of lactate to the sediment slurry also resulted in stimulation of sulphate reduction (Table 1) but, unlike the other substrates, lactate was initially degraded by fermentation with only a small contribution from oxidation at the expense of sulphate. Large numbers of anaerobic fermentative bacteria were also observed in the lactate agar shakes. Metabolism of lactate by fermentation only would have resulted in an acetate:propionate ratio of $1: 2$ and a contribution from oxidation would have increased the amount of acetate produced. As an acetate: propionate ratio of approximately $1: 1$ was found (Fig. $1 b$ ), this indicates a significant contribution of oxidation (about $25 \%$ ) which was consistent with the increase in sulphide levels observed during the first $4 \mathrm{~d}$ of the experiment. Propionate, one of the fermentation products of lactate (Fig. $1 \mathrm{~b}$ ), was subsequently oxidized to acetate with concomitant sulphate reduction. At the end of the incubation period a significant increase in $\mathrm{n}-\mathrm{C}_{17: 1}$ and $\mathrm{n}-\mathrm{C}_{15: 1}$, the biomarkers for Desulfobulbus, was observed (Table 2), but not in br- $\mathrm{C}_{17: 1}$ or br- $\mathrm{C}_{17: 0}$, the biomarkers for Desulfovibrio (Taylor \& Parkes, 1983). This result is consistent with propionate being the main substrate for sulphate reduction during the experiment and from the evidence of viable counts (Table 2) which also shows the major stimulation to be that of the propionate-utilizing sulphate reducers.

In an attempt to find which sulphate-reducing bacteria were involved in the initial degradation of lactate (both Desulfobulbus and Desulfovibrio are capable of using lactate directly), the lactate slurry incubation was repeated but was stopped after $3 \mathrm{~d}$ when the lactate has almost completely disappeared and before propionate oxidation had become a significant process (Fig. $1 b$ ). Neither $n-C_{17: 1}$ nor br- $\mathrm{C}_{17: 1}$ was stimulated, which was consistent with only a small contribution of sulphate reduction to lactate mineralization during this period. This result also shows that although Desulfobulbus is capable of fermenting lactate (Laanbroek \& Pfennig, 1981; Widdel \& Pfennig, 1982) it is not the major lactate-fermenting organism in this sediment slurry. These results also indicate that Desulfovibrio played only a minor role if any in the oxidation of lactate in these slurries.

Although there was a small increase in the total biomass (as measured by lipid phosphate, Table 2) in all the slurries where substrate was added compared to the control $(13 \mathrm{~d})$, this increase was not statistically significant. Similarly there was no significant change in the total fatty acids in the $C_{12}-C_{18}$ range where a bacterial contribution would occur (Kates, 1964). Thus addition of substrate to the sediment slurries appears to have resulted in subtle changes in the community structure rather than large changes in the bacterial biomass.

In the hydrogen-supplemented Loch Eil Slurry (Table 3), $\mathrm{n}-\mathrm{C}_{17: 1}$ was the only bacterial fatty acid to be significantly $(P=0.01)$ stimulated. The stimulation was less than for either the lactate or propionate slurries, probably due to a combination of lower substrate concentration and 
$\mathrm{n}-\mathrm{C}_{17: 1}$ being present at lower concentrations when Desulfobulbus is grown on hydrogen compared to lactate or propionate (Taylor \& Parkes, 1983). There was no stimulation in br$\mathrm{C}_{17: 1}$, the biomarker for Desulfovibrio desulfuricans, with hydrogen, which was surprising as it has been suggested (Laanbroek \& Pfennig, 1981 ; Banat et al., 1981) that Desulfovibrio sp. may be an important hydrogen scavenger in marine sediments. Our results indicate that a Desulfobulbusand not a Desulfovibrio-type bacterium may be the main hydrogen-scavenging sulphate-reducing bacterium within marine systems. However, caution has to be exercised when relating the results of these slurry experiments to natural sediments, where substrate concentrations are low, as populations stimulated by additions of high concentrations of substrates may be different to the in situ community.

At least two functional groups of sulphate-reducing bacteria have been demonstrated to be present within marine sediments (Banat et al., 1981), one group oxidizing acetate and another utilizing hydrogen. Our data support this, as acetate and hydrogen, although both stimulating sulphate reduction, produced different profiles of bacterial fatty acids. Desulfobacter sp. seems to be the main acetate utilizer both in the slurry and in the original sediment, whereas Desulfobulbus seems to be responsible for propionate oxidation and also for hydrogen consumption within the slurries. These data bring into question the role of Desulfovibrio desulfuricans within the marine environment. This organism has often been shown to be present at high concentrations within marine sediments, using lactate based culture medium (e.g. Laanbroek \& Pfennig, 1981), and hence it is surprising that its fatty acid biomarker (br- $\left.\mathrm{C}_{17: 1}\right)$ was not stimulated in any of the sediment slurries. This discrepancy probably reflects the opportunistic nature of Desulfovibrio and the non-specific substrate conditions that using lactate medium may provide $(a)$ because if lactate-fermenting bacteria are present, lactate will be rapidly converted to substrates that Desulfovibrio cannot use, e.g. acetate and propionate, and therefore colony counts on lactate medium may not necessarily reflect lactate-utilizing organisms; and (b) both Desulfovibrio and Desulfobulbus are able to grow on lactate agar shakes.

Replicate experiments with a different marine sediment (Loch Etive, Tables 1 and 3) showed an identical result with regard to stimulation of $n-C_{17: 1}$ when incubated with added propionate, demonstrating that the initial results are not specific to Loch Eil sediments and suggesting the general applicability of fatty acid biomarkers as a tool for the study of mixed sulphate-reducing bacterial populations, within complex marine sediments.

We would like to acknowledge the technical assistance provided by W. Buckingham during this work and the helpful advice and constructive criticism of Professor S. Elsden. Assistance with statistics was kindly provided by Dr J. Fry, UWIST, Cardiff.

\section{REFERENCES}

Banat, I. M., Lindstrom, E. B., Nedwell, D. B. \& BalBa, M. T. (1981). Evidence for coexistence of two distinct functional groups of sulfate-reducing bacteria in salt marsh sediment. Applied and Environmental Microbiology 42, 985-992.

CLINE, J. D. (1969). Spectrophotometric determination of hydrogen sulphide in natural waters. Limnology and Oceanography 14, 454-458.

Douglas, A. G., Hall, P. B., Bowler, B. \& WILliams, P. V. P. (1981). Analysis of hydrocarbons in sediments as indicators of pollution. Proceedings of the Royal Society of Edinburgh 80B, 113-134.

Federle, T. W., Livingston, R. J., Neeter, D. A. \& WhITE, D. C. (1983). Modifications of estuarine sedimentary microbiota by exclusion of epibenthic predators. Journal of Experimental Marine Biology and Ecology 73, 81-94.

Gillan, F. T., Johns, R. B., Verhegen, T. V., Nichols, P. D., EsDaile, R. J. \& Bavor, H. J. (1983). Monounsaturated fatty acids as specified bacterial markers in marine sediments. In Advances in Organic Geochemistry 1981, pp. 198-206. Edited by M. Bjorøy. Chichester: John Wiley \& Sons.

HowARTH, R. W. (1978). A rapid and precise method for determining sulfate in seawater, estuarine water and sediment pore waters. Limnology and Oceanography 25, 1066-1069.

JøRGENSEN, B. B. (1982). Mineralization of organic matter in the sea bed - the role of sulphate-reduction. Nature, London 296, 643-645.

Kates, M. (1964). Bacterial lipids. Advances in Lipid Research 3, 17-90.

KING, J. D. \& WhITE, D. C. (1977). Muramic acid as a measure of microbial biomass in estuarine and marine samples. Applied and Environmental Microbiology 33, 777-783.

LaAnbroek, H. J. \& Pfennig, N. (1981). Oxidation of short-chain fatty acids by sulphate-reducing bacteria in freshwater and marine sediments. Archives of Microbiology 128, 330-335. 
LeCheValieR, M. P. (1977). Lipids in bacterial taxonomy - a taxonomist's view. Critical Reviews in Microbiology 5, 109-210.

LeChEVAliER, M. P. (1982). Lipids in bacterial taxonomy. In Handbook of Microbiology, 2nd edn, vol. 4, pp. 435-541. Edited by A. I. Laskin \& H. A. Lechevalier. Boca Raton, Florida: CRC Press.

Malcolm, S. J. (1981). The Chemistry of Sediments of Loch Etite, Scotland. PhD thesis, University of Edinburgh, UK.

Metcalfe, L. D. \& Schmitz, A. A. (1961). The rapid preparation of fatty acid esters for gas chromatographic analysis. Analytical Chemistry 33, 363-364.

PARKeS, R. J. \& TAYloR, J. (1983a). The relationship between fatty acid distributions and bacterial respiratory types in contemporary marine sediments. Estuarine, Coastal and Shelf Science 16, 173-189.

PARKes, R. J. \& TAYLOR, J. (1983 $b$ ). Analysis of volatile fatty acids by ion-exclusion chromatography, with special reference to marine pore water. Marine Biology 77, 113-118.

Pearson, T. H. (1981). The Loch Eil Project introduction and rationale. Journal of Experimental Biology and Ecology 55, 93-102.

PfenNig, N., Widdel, F. \& TRÜPer, H. G. (1981). The dissimilatory sulfate-reducing bacteria. In The Prokaryotes, vol. 1, pp. 926-940. Edited by M. P. Starr, H. Stolp, H. G. Trüper, A. Balows \& H. G. Schlegal. Berlin \& New York: Springer-Verlag.

SHaw, N. (1974). Lipid composition as a guide to the classification of bacteria. Adrances in Applied Microbiology 17, 63-108.

SoKAL, R. R. \& RohlF, F. J. (1969). Biometry, The Principles and Practice of Statistics in Biological Research. San Francisco: W. H. Freeman \& Co.

Sørensen, J., Christensen, D. \& Jørgensen, B. B. (1981). Volatile fatty acids and hydrogen as substrates for sulphate reducing bacteria in anaerobic marine sediment. Applied and Entironmental Microbiology 42, 5-11.

TAYLOR, J. \& PARKes, R. J. (1983). The cellular fatty acids of the sulphate-reducing bacteria, Desulfocibrio sp., Desulfohulbus $\mathrm{sp}$. and Desulforibrio desulfuricans. Journal of General Microbiology 129, 3303-3309.
VAN Es, F. B. \& MEYER-ReIL, L. A. (1982). Biomass and metabolic activity of heterotrophic marine bacteria. In Advances in Microbial Ecology, vol. 6, pp. 111-170. Edited by K. C. Marshall. New York \& London: Plenum Press.

White, D. C. (1983). Analysis of microorganisms in terms of quantity and activity in natural environments. In Microbes in their Natural Environments, Society for General Microbiology Symposium, vol. 34, pp. 37-66. Edited by J. H. Slater, R. Whittenbury \& J. W. T. Wimpenny, Cambridge: Cambridge University Press.

White, D. C., Davis, W. M., Nickels, J. S., King, J. D. \& BobBIE, R. J. (1979). Determination of the sedimentary microbiol biomass by extractable lipid phosphate. Oceologia 40, 51-62.

WIDDEL, F. (1980). Anaerober Abbau von Fettsäuren und Benzoesäure durch neu isolierte Arten Sulfatreduzierender Bakterien. Doctoral thesis, University of Göttingen, FRG.

Widdel, F. \& Pfennig, N. (1981). Studies on dissimilatory sulfate-reducing bacteria that decompose fatty acids. I. Isolation of new sulfate-reducing bacteria enriched with acetate from saline environments. Description of Desulfobacter postgatei gen. nov., sp. nov. Archives of Microbiology 129, 395-400.

Widdel, F. \& Pfennig, N. (1982). Studies on dissimilatory sulfate-reducing bacteria that decompose fatty acids. II. Incomplete oxidation of propionate by Desulfobulbus propionicus gen. nov., sp. nov. Archives of Microbiology 131, 360-365.

Widdel, F., Kohring, G. \& MAYER, F. (1983). Studies on dissimilatory sulfate-reducing bacteria that decompose fatty acids. III. Characterization of the filamentous gliding Desulfonema limicola gen. nov., sp. nov., and Desulfonema magnum sp. nov. Archives of Microbiology 134, 286-294.

WINFREY, M. R. \& WARD, D. M. (1983). Substrates for sulfate reduction and methane production in intertidal sediments. Applied and Environmental Microbiology 45, 193-199. 